\title{
THE FUSION OF ARCHAIC AND MODERN FEATURES IN THE SCULPTURES BY ALFIZ SABIROV
}

\author{
Mileusha Mukhametzyanovna Khabutdinova, \\ Kazan Federal University, \\ 18 Kremlyovskaya Str., Kazan, 420008, Russian Federation, \\ mileuscha@mail.ru. \\ Luiza Firdusovna Zamalieva, \\ Kazan Federal University, \\ 18 Kremlyovskaya Str., Kazan, 420008, Russian Federation, \\ zamalluiza@mail.ru.
}

\begin{abstract}
The article is devoted to Alfiz Sabirov's original mythological images and the specificity of his Old Turkic history interpretation. It systemizes critical reviews of the works by the young sculptor, who has taken part in a great number of exhibitions both in Russia and abroad, and describes A. Sabirov's significant "artifacts". The research focuses on the works presented at the solo-exhibition "Ayu bala" ("The Baby Bear") in Kazan (2019).
\end{abstract}

Key words: Tatar culture, sculpture, Alfiz Sabirov, mythology, image, tradition.

\section{Introduction}

Sculptor Alfiz Sabirov's solo exhibition "Ayu Bala", held in the National Art Gallery "Hazine" in the Kazan Kremlin (05.09.19-02.10.19), became a significant event in the cultural life of Kazan. The slogan "From ancestors to descendants" very accurately conveys the artistic conception of the exhibition enabling visitors to plunge into the world of A. Sabirov's personal mythology. The sculptor, who originally comes from Perm, graduated from the Ilya Glazunov Russian Academy of Painting, Sculpture and Architecture. A. Sabirov is a member of the All-Russian Creative Public Organization "Artists Trade Union of Russia". In 2017, the author of the "Ayu Bala" exhibition won the the Baki Urmanche Prize of the Ministry of Culture of the Republic of Tatarstan.

The aim of our study, based on the works presented at the exhibition in Kazan in 2019, is to identify the characteristics of personal mythology, created by the Tatar sculptor born in the Perm region.

\section{Materials and methods}

In this work, we used the method of formal and stylistic analysis in order to identify and theoretically underpin the main sculptural trends in A. Sabirov's works; the comparative historical method to identify the stylistic peculiarities of his main works; the descriptive method to characterize the author's individual approaches to imagery and sculptural embodiment of the main topics.
The study describes the sculptures, presented at A. Sabirov's solo exhibition "Ayu Bala", and presents the very first attempt to analyze the features of Alfiz Sabirov's imagery and sculptural language.

The methodological basis comprises the works devoted to the history of the material and spiritual culture of the Tatar people ([Valeev], [Valeev, Valeeva-Suleimanova], [Valeeva, 1999], [Valeeva, 2003], [Davletshin], [Sultanova, 2000], [Sultanova, 2015], [Chervonnaia] and others), and Tatar sculpture [Krivosheeva]

\section{Discussion}

Since 2004, Alfiz Sabirov has been actively participating in exhibitions both in Russia ("The Legend Has It" (Perm, 2011), "Art-Kazan" (Kazan, 2011), "Big Volga" (Kazan, Perm, Moscow, 2011), "Art-Perm" (Perm, 2011-2013), "Global Art Community" (Perm, 2013), and abroad ("From the Urals to the Atlantic" (Latvia, Riga, 2014), "L'OURAL - artistes en mouvement" (France, Grenoble, 2014), "Antichambre des merveilles" (France, Paris, 2015), "From the Pacific to the Atlantic" (France, Paris, 2015), "Russian Diary in Paris" (France, Paris, 2015), "Perm-Grenoble. Artistes croises" (France, Grenoble, 2016), "Nouvel artefact" (France, Paris, 2016), "Gardien" (France, Meximieux, 2016)). The sculptor's works are kept in private collections both in Russia (Moscow, St. Petersburg, Yekaterinburg, Perm, Tyumen, Kras- 
noyarsk) and abroad (Paris, Grenoble, New York, London, Riga, Tokyo).

During the opening ceremony of the "Ayu Balla" exhibition in Kazan, A. Sabirov admitted that he became interested in sculpture in his third year at the Ilya Glazunov Russian Academy of Painting, Sculpture and Architecture (the Ural branch). The young sculptor wanted to try his hand at volume and understand if he could tame the bronze. Since then, it has become his favorite material, and playing with textures, volume and truncated shapes have become his signature creative techniques. In his works, A. Sabirov uses metal in combination with stone.

R. Lobatskaya, head of the Department of Design and Technology, Professor of Irkutsk National Research Technical University, believes that A. Sabirov's creative work should be considered within the framework of the trend, which can be described as "intellectual symbolism": "Modern indoor sculpture is a unique art form. It is complex, but very capacious and expressive. The movement, which Alfiz Sabirov follows, can be called intellectual symbolism. Its characteristic features are: the combination of various materials in one work, the use of jewelry technology, and the resort to ethnic roots. Now, all over the world, ethnics is sprouting with absolutely extraordinary works" (Quoted from: [Kokin]).

Art critic O. Vlasova points out that "Alfiz Sabirov's creative work is based on the theme of the author's mythology associated with traditions and legends of the Tatar people. The author's mythological characters come from these legends, describing individual episodes from the past of a particular ethnic group. Based on realistic interpretations, the characters of the harsh and warlike world of nomads ("Defeated") or the images of oriental beauties ("A Sitting Female", "Aisulu") cannot be attributed to the category of historical illustrations either. It is rather a kind of allusion, the author's attempt to interpret and a desire to "read", comprehend and embody the spirit of the time. At first glance, the sculptures by Alfiz Sabirov may seem too abstract and difficult to identify, as they are filled with a great number of symbols and meanings. Exotic themes, a bizarre fusion of archaic and modern features, numerous reminiscences and correlations with both traditional folklore tales and post-modern approach to form, create the original author's style" [Interview with O. Vlasova].

In a number of his interviews, A. Sabirov mentions that Turkic mythology served as a fertile ground for the formation of his authorial mytholo- gy. The sculptor drew inspiration from the works of O. Rodin, G. Moore, K. Brancusi, and B. Urmanche.

The art critic R. Sultanova believes that "A. Sabirov's creative work is developing on the basis of oriental Turkic culture, divine inspiration, and deep love": "He found a worthy source for his sculptural ideas: primarily in mythological representations and beliefs. He is in line with the development of ethnically oriented Tatar sculpture, which is closely connected with the ancient Turkic sculptures and the applied art of the Volga Bulgaria.

Sabirov expands the paths for the further development of Tatarstan's sculpture towards postmodernism, discovered back in the early 1970s by the monumental artist Ildar Khanov. Using the tendencies of modernism just like Khanov, the young sculptor conveys ethnic archetypes of shapes, tridimensional vision of the national archaic images through the sculptural form. Sabirov confidently paves the way for the development of ethnic traditions, which manifest themselves not only in the formal language, but also in the understatement, non-literality, ambiguity, associativity characteristics of the Oriental art and the artistic thinking of the Tatars, when the techniques of ancient ethnic style and Russian and European schools can be combined in one work.

In some works, Muslim traditions are revealed in the lack of image, connection with a line, calligraphy, and the arabesque tendency.

With his work young sculptor Alfiz Sabirov proves once again that it is difficult to follow one tradition in modern art: the avant-garde trends of world art have opened the way to the synthesis of various cultures [Sultanova, 2019].

A. Sabirov deliberately resorts to Turkic words when designing the names of his works and exhibitions. The sculptor turns them into the "keys" to the "doors" into a new, different world. A. Sabirov strives to create his own story, therefore, he resorts to the potential of his mother tongue.

Reflecting on the richness of his mother tongue, A. Sabirov posted the following message on the social network "Vkontakte" on 14 August, 2019: "At, yau, ayu, ut, su, ash, uy, oyu, ul are all Tatar words consisting of only two letters. Some of them can be found in my sculptures. I pay great attention to what the work will be named, what it will sound. They (words) reflect foundation, strength, antiquity, and time. And the list of words can be continued: az, yal, yat, uk, it, iyu, as, ay, yel, yaz, il...". According to the Tatar writer Mar- 
cel Galiev, "the most precious, vital words in our language are presented in a surprisingly short form, as if condensing all the energy of fire and meaning in the depths of their core:

"Zhir. Kuk. Kan. Ten. Mon. Din. Zhan. Rukh."1

They are short words that are pronounced all in one breath ("Rukh" ("Poetry of the Spirit")) [Galiev, p. 39].

The sculptor very carefully selects names for his personal exhibitions. For example, in 2013, A. Sabirov opened an exhibition in Perm and called it "Komeshtashtan. Born from Pearls". "Komeshtashtan" can be literally translated from Tatar as "from silver stone". In an effort to convey the essence of his creative intention, the sculptor duplicates the name in Russian. Thus, the sculptor emphasizes the multi-layered nature of the semantics of his work. The inner force permeates the sculpture "Komeshtashtan. Born from Pearls" (Bronze, molding. 2013. 9x21x19). It seems that the heroic essence of the mythological creature emerges from its shell. The bronze horns are polished to have a golden glow.

A. Sabirov deliberately changes familiar words in order to avoid a straightforward interpretation of his images, since the narrative layer in his works becomes part of the image. Thus, his exhibition in Perm in 2014 was called "Bator. Touch". Although the sculptor resorts to images of heroes in every exhibition as a leitmotif, he preferred to abandon the regular word "batyr" ("hero, brave, brave warrior"), which usually denotes names of heroes of legends and fairy tales in Turkic languages [TatarRussian Dictionary, p. 207]. In an effort to deeper express the process of transformation of the image in time, the sculptor shows this process not only externally, but also internally. Thus, the character of A. Sabirov's sculpture "Bator / Touch" (Bronze, molding. 2014. $43 \times 27 \times 17$ ) breaks the time line like an icebreaker and undergoes changes, finding himself in new conditions.

The sculptor also resorted to the same narrative technique when selecting the name for "Balla" (Bronze, molding. 2013. 11x8x6). (compare it with "bala" ("child, baby")). As the author himself admits, he doubled "l" in order to achieve melodiousness in the title of the work and create some mystery. We can see a little girl whose braids act as a talisman, and whose posture implies that she might be a princess.

\footnotetext{
${ }^{1}$ Earth. Sky. Blood. Body. Song. Belief. Soul. Spirit (in Tatar).
}

In the sculpture "At/Horse" (Bronze, molding. 2013. 11x 14x5), A. Sabirov uses bronze to embody the strength and good energy of the patron of heroes from Turkic myths. The use of colour adds to the meaning and appeal: a dappled horse - the batyr's devoted magical friend and assistant - appears from a haze of centuries. A horse is an integral part of life in the steppe, helping people to live and survive, therefore the sculptor seeks to convey the strong connection of the horse with the earth and the fact that this animal is the support of man.

A. Sabirov "plays with ambiguity, sowing the seeds of confusion where it can be tempting," says the art critic Victoria Kutdusova. The sculptor "skillfully works with shapes, artistically conveys the internal emotional state, which is revealed through body language and gestures. The author demonstrates a fascinating play of form and content, using bronze, he creates amazing sculptures that convey powerful internal strength and unpredictability.

"Considering the works by Alfiz, you understand that there is something mysterious and enigmatic hidden in them. The sculptures are always immediate: they seem to be still in the process of transformation. They seemed to be from another world, as if they had fallen from space and cooled in our earthly kingdom. The lines and shapes create a free rhythm, the boundaries of the work become fuzzy, this rhythm carries you further, and your eyes smoothly flow from one sculpture to another, each having its own music and leading motive. The sculptures by Alfiz ignite imagination and force us to look for the answer to the mystery hidden in them," art critic Victoria Kutdusova shares her observations [Kutdusova. Exhibition Abstract].

So, the image of Bars Tabar (Bars Tabar 2. Bronze. Molding. 2013. $34 \times 33 \times 14$ ) is an embodiment of a mythical creature and intertwined epochs. While the coarse, rough, and stony body symbolizes the past, the perfectly polished, smooth face shows the signs of the present and future. The way we see it, the forms smoothly transitioning from one to another symbolize a dynamic character inherent in the meeting point of times. The idea of time is expressed in the combination of the rough relief of the body surrounded by changing environment, movement is implied by the name of the mythical creature (the word "tabar" in translation means "will find, seeking"). Its rough body only emphasizes the polished surface of the face with one eye seen as if in profile. 
A. Sabirov creates a myth about himself. It is evidenced by his first sculpture "A Boy with a Sword" (Bronze, molding. 2009. 6x6x2). The sculptor's young character is looking to the future, ready to encounter life. The toy sword adds to the confidence and strength of his posture. The boy's haircut is a tribute to the Turkic tradition. Nomadic Turkic peoples grew a hair forelock called "kekil" to fend off the evil eye. Turkic peoples also had the hairstyle called "aidar": the Great Steppe peoples cut off their hair on the head keeping one large tuft of hair on the back of their heads untouched, which was braided for convenience. This haircut for males was considered by the Tengrians a talisman for protection.

A. Sabirov's sculpture "Little Warrior. Helmet" (Bronze, molding. 20x17x7.) is based on this image. The conflict here is created by the contrast between the heavy helmet and the feeble body of the child. The sculptor managed to convey the dynamic energy of the boy's resistance to the heavy burden, which inspires the audience to believe that in the future this child will turn into a defender, a real warrior: the child's bare feet are pigeon toed not to let it fall down; and the aidar on the helmet is directed upwards. The texture of the materials, the helmet and sword are made from, has a huge impact on perception. The helmet is rough and covered in patches as a visible reminder of the heroes who perished in battle. The idea of protection is expressed not only in the helmet, but also in the little braid. The contrast is made between the wooden sword, used during training, and the combat helmet. The antithesis of these images enables viewers to visualize the movement of time, see the change of generations. This meaning is supported by the empty eye sockets on the helmet, behind which our imagination can draw orderly ranks of the warriors of the past. The smooth body of the child and the relief surface of the helmet mark the connection between generations, the continuity of heroism. The shape of the arms and the shield indicate the boy's readiness to perform a feat in the future.

We were highly impressed by the sculpture "Defeated. 2" (Bronze, molding. 2013. 24x18x15), praising the inner strength of the Hero. According to the art critic O. Vlasova's apt remark, the theme of the works by A. Sabirov "is based on myths and legends of Tatar epos, telling about life and death, struggle and peace, tragic finiteness and elevated existential poetry. In the author's view, nature and man are connected by the unified laws of life, where vital energy is guided by a powerful spiritu- al impulse" [Vlasova]. The sculpture "Defeated. 2" depicts a warrior caught unawares by his enemy's arrow. However, being in a difficult situation, he remains faithful to his principles - he is resisting. It does not matter where the arrow came from, it is more important to look at the bowed head, hands rested on one sides, lips pressed together, and the characteristic inclination of the braid. The warrior's face expresses firmness, his facial expression does not suggest any suffering and despair in the face of the imminent death. Following the author's vision, the surface of the sculpture is deliberately rough and ascetic, covered with patina - "a touch of time". The name of the sculpture enters into a kind of confrontation with the warrior's figure, showing the audience the strength fortitude lurking in a person and the greatness of life. As the author of the sculpture admits, he wanted to convey the paradox of being, where life and death go side by side.

It is surprising how organically the sculptor fuses his childhood memories of the events and legends of his native village with the images of ancient Turkic mythology. "Basing on the images born in his dreams, childhood memories and thoughts, he creates surprisingly complex, in terms of structure, but very familiar images. We see many familiar elements in his works. Each sculpture carries personal information that is hidden on its surface. Watching the play unfolding in front of our eyes, with the participation of unicorns from his village, mysterious princesses, mythical monsters and mysterious beasts, it seems that you can see the whole cultural heritage of the past millennia, as V. Kutdusova thinks. Each figure is special, unique, and beautiful. One of the main characters is "A Unicorn from Our Village" (Bronze, mold-

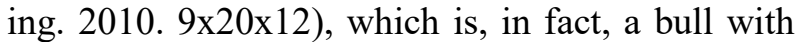
one horn, powerful, squat, a bit clumsy and somewhat flawed, but retaining its stamina. We can also mention "At. Horse" (Bronze, molding. 2013. 13x15x5.), "The Sentinel" (Bronze, molding. 2011. 26x15x5.), "Azhdaha" (A Dragon) (Bronze, molding. 2011. 14x20x9) "Tai Kyz" (a horse-girl) (Bronze, molding. 2011. 13x11x4) and "A New Centaur" (Bronze, molding. 2017. 34x12x18), where the rider and the six-legged horse merge in a single impulse." [Kutdusova].

As Alfiz Sabirov admits, his works are not directly related to epos. He creates his own fantasy, even phantasmagoric images. For Alfiz, ethnic features in the faces of the sculptures are no more than a reference to ancestral roots. 
The artist creates a new, very personal mythology in which ancient ethnic myths seem to have been run through a multimedia program. This incredibly organic combination of archaic and modern features is emphasized with a play of textures: his sculptures often simultaneously have a bumpy, dust-filled surface of a raw ingot placed end to end with polished bronze with a golden shine.

The art critic O. Vlasova believes that A. Sabirov is characterized by "subconscious emotionality: horses, female beauty, male valour..." ([Interview with O. Vlasova]).

The sculpture "Princess. 2" stands out among other female sculptures (Princess 2. Bronze, stone, molding. 2017.29x12x9). The tender, fragile, vulnerable, perhaps capricious teenage girl is holding either a grain (a symbol of all life) or a pearl (a symbol of the sky) in her hands. This sculpture shows peace and confidence of the future.

The spirit of harmony and inner bliss is also present in the image of "Su kyz" (Bronze, molding, wood. 2013. 39x28x12). The mysterious watergirl, whose body is covered with green patina, breaks all the existing concepts of female anatomy. The sculptor managed to create a self-contained image: nothing is able to disturb the inner peace of the heroine, no matter what storms rage on the surface of the water.

The theme of motherhood is raised by the sculptor in the sculpture "Ana Arslan" in a very quaint way (Bronze, molding. 2014. 16x33×9).

"Girl", "Princess", "Memories of the Sea", "Skull", "The Dawn of the First Day" are very different images in terms of their sculptural forms. As indicated by O. Vlasova, "the compositions of the sculptures are complex and varied. Some of them express rapid movement, the others express "archaic" stillness and silence, all the figures seem to be embedded in a cube and layered into separate tiers. Such compositions clearly convey the traditions of oriental sculpture. A huge effect is achieved by processing texture. Some areas have a rough and lumpy surface of a "natural" ingot, in other areas the bronze is polished to have a dazzling golden glow. The stone foot only emphasizes the elasticity, flexibility, the "engraved" beauty of the material, sometimes made livelier by some inlay or the use of wood and shells.

One easily feels that the artist is attracted by the play of textures, materials, complex interactions of shapes and space.

Modern art is becoming more and more symbolic requiring deep knowledge and great imagination efforts from the viewer. These aspirations are read in every work of the artist, who feels the dramatic nature of the history and poetry of eternal life values" [Vlasova].

"Modern society lives a fast-paced life and does not have the time to focus on details. According to the art critic V. Kutdusova, A. Sabirov's works make the chaos surrounding us stop and urge us to freeze in silence and peace" [Kutdusova].

Our attention was attracted by the sculpture "Tamchi" (Bronze, molding, silvering, phianites. 2013. 3x9x4 mm). The name means a "drop" in the Tatar language. The life-giving force of moisture is embodied in the blue phianite in the mouth of a mythical bug, whose eyes are made of rubycolored phianite and are looking at a distant target. In our opinion, this sculpture symbolizes the eternal search for truth and the eternal movement.

The artist's throbbing thought was embodied in the image of "Insomnia", which has the shape of a stingray (Insomnia 2. Bronze, molding. 2013. $41 \times 61 \times 11$.). The author psychologically reliably conveys the state of active thinking of someone wide awake. To convey this, the sculptor fills the wavy surface with many eyes. Insomnia spreads around like water and imperceptibly envelops its victim. The polished surface reflects fluidity and the ability to absorb the color of the surrounding space.

A. Sabirov admits that he seeks to create a syncretic image which contains visual elements that refer to different cultures: Tatar, ancient Greek, Chinese, etc. For the sculptor, "the mix of different cultures" is a way to tell his personal story. The sculptor achieves the inner richness of the image in order to build a dialogue with his viewer. In order to stimulate the audience's imagination, A. Sabirov creates works with truncated elements. They are a kind of new artifacts like those that came to us in the form of fragments and are stored in archaeological museums [Belomestnova].

A. Sabirov calls himself an adherent of nonclassical sculpture: "I strive to destroy forms and volumes (and through this destruction, to transform the image in a mythological context), as well as to combine different textures, for example, rough and perfectly polished. Striking discrepancies with expectations and proportional changes captivate the viewer and create a new vision of the images. However, they cause strong aversion in some people" [Belomestnova].

The sculptor seeks to show the duality of the world. The unity and struggle of male and female elements, hardness and fluidity, lines and textures, 
colors and shapes. His works remind of mythical characters from Ancient Greece, Rome, and Babylon, inspired by the history of the past.

A. Sabirov is not afraid to rethink famous images. For example, Rodin's "The Thinker" looks quite different nowadays, as if on the way to a more complex rebirth in the modern world.

\section{Results}

The main image of A. Sabirov's Kazan exhibition was "Ayu bala" (Bronze, molding. 2017. $39 \times 32 \times 24$ ), which means "a baby bear" in the Tatar language. The image itself was inspired by the sculptor's childhood memories. In the family where he grew up there was a traditional wish to a child: "Ayu bala kebi taza bul!" - "Be as strong as a bear!", "Be as brave as a bear", "Remember, you have descended from the kin of the white wolf!"

The folklorist M. Mingazhetdinov, who first described the "Ayyu Tuyy" festival (The Bear Festival), suggested that the legends about fairy-tale heroes, miraculously born by the bear, date back to the Turkic-Mongolian ethnic cultural environment, and later penetrated the folklore of other peoples [Mogilnikov, pp. 156-157]. In the village called Ebargul (the Ust-Ishim district in the Omsk Oblast, where Kurdak-Sargat Tatars live), the host of the forest was called Ayu Babai (literally "Grandfather Bear"). The image of Ayu Babay is closely associated with the image and the cult of the bear [Iarzutkina]. In his works, I. Belich, analyzing the cult of the Barabinsk Tatars, describes the prohibitions observed by the Barabinsk hunters, as well as the amulets that they kept to attract "good luck" [Belich].

The sculptor admits that in this work he wanted to emphasize the importance of parents' influence in raising a child: "from the early childhood, a child is endowed with protection and programmed by its parents from generation to generation." The conflict in the sculpture is achieved through the contrast of the heavy mask and the body of the baby, whose heels are a symbol of defenselessness (cf. "Achilles' heel"). The burden of knowledge and traditions with which the child will step into the future depends entirely on the parents. It is they who give the baby the Life Force.

A. Sabirov has embarked upon the path of mastering the traditions of ancient Turkic culture, we want to believe that in the future Ayu Bala will grow into Ayu Babai, a worthy successor to the traditions of the great Baki Urmanche.

"The works by the sculptor Alfiz Sabirov, presented at the exhibition, are a journey of a hero, living in each of us, into the enchanting world of mythology, based on the traditions of the Tatar people. The exhibition's slogan is "From ancestors to descendants".

During this journey, the viewer will be able to observe the images of chthonic giants, mythical animals, heroes and gods that can help people realize the paradoxes of being: the relationship between love and hate, chaos and space, life and death, the ancient and the new.

Conflicts and transformations are happening at the junction of times, connecting generations. The sculptures themselves have transitional forms, as if they were transforming in front of the viewers' eyes [Abstract of "Ayu Bala" exhibition].

\section{References}

Abstract of "Ayu Bala" exhibition (Kazan, 2019).

Belich, I. V. (1989). Priroda $v$ doislamskikh verovaniyakh sibirskikh tatar (konets XIX nachalo XX $v v$.) [Nature in the Pre-Islamic Beliefs of the Siberian Tatars (late $19^{\text {th }}$ and early $20^{\text {th }}$ centuries)]. Kul'turnye $i$ khoziaistvennye traditsii narodov Zapadnoi Sibiri, Novosibirsk, pp. 133-140. (In Russian)

Belich, I. V. (1999). Kul't medvedia u sibirskikh tatar [The Cult of the Bear among the Siberian Tatars]. Obskie Ugry. Proceedings of the $2^{\text {nd }}$ Siberian Symposium "Cultural Heritage of the Peoples of Western Siberia”, Tobolsk, Omsk, pp. 86-90. (In Russian)

Belomestnova, A. (2016). Novye artefakty Al'fiza Sabirova [New Artifacts of Alfiz Sabirov]. Berlogos. URL: $\quad$ http://www.berlogos.ru/interview/novyeartefakty-alfiza-sabirova/ (accessed: 15.12.2016). (In Russian)

Chervonnaia, S. M. (1987). Iskusstvo Tatarii. Istoriia izobrazitel'nogo iskusstva $i$ arkhitektury $s$ drevneishikh vremen do 1917 goda [The History of Fine Arts and Architecture from Ancient Times until 1917]. 352 p. Moscow. Iskusstvo. (In Russian)

Galiev, M. (2014). Rukh. Poeziia dukha [Ruh. Poetry of the Spirit]. 271 p. Kazan, Tat. kn. izd-vo. (In Russian)

Davletshin, G. M. (2004). Ocherki po istorii dukhovnoy kul'tury predkov tatarskogo naroda (istoki, stanovleniye, razvitie) [Essays on the History of the Spiritual Culture of the Tatar People's Ancestors (sources, formation, development)]. 431 p. Kazan, Tat. kn. izd-vo. (In Russian)

Iarzutkina, A. A. (2004). Traditsionnye zemledel'cheskie, skotovodcheskie $i$ promyslovye kul'tury sibirskih tatar: avtoref. dis. ... ist. kand. ist.n. [Traditional Agricultural, Livestock and Commercial Crops of Siberian Tatars: Ph.D.]. Omsk, 18 p. (In Russian)

Interview with O. M. Vlasova. Alfiz Sabirov's personal archive.

Kokin, A. (2017). Intellektual'nyi simvolizm A. Sabirova [Intellectual Symbolism of A. Sabirov]. Argumenty nedeli. Issue 3 (545). Irkutsk. (In Russian) 
Krivosheieva, T. N. (2013). Skul'ptura Tatarstana: istoki, stanovleniye, traditsii [Sculpture of Tatarstan: The Origins, Formation, Traditions]. 256 p. Kazan, Otechestvo. (In Russian)

Kutdusova, V. Mifologicheskoe soznanie. Estetika mifa. Annotatsiia vystavki. [Mythological Consciousness. Aesthetics of the Myth. Abstract of the Exhibition]. (In Russian)

Kutdusova, V., Sabirov, Alfiz. Perm. URL: http://www.yarmarka.ru/content/2016/art_russia/catalog /sabirov.html. (accessed 21.10.2019). (In Russian)

Mogil'nikov, V. A. (1971). K voprosu o svyazyakh naseleniya Bashkirii $i$ Zaural'ia v kontse I tysyacheletiia do n.e. -1 tysyacheletii n.e. [On the Issue of Relations between the Population of Bashkiria and Far Ural at the End of the 1st Millennium BC -1 Millennium AD]. Arkheologiya i etnografiya Bashkirii, Volume 4, Ufa. pp. 151-157. (In Russian)

Pandzharidi, V. (2016). Mify $i$ legendy Al'fiza Sabirova [Alfiz Sabirov's Myths and Legends]. Information Agency "Magnesia". URL: https://www.mngz.ru/russia-world-sensation/2222342mify-i-legendy-alfiza-sabirova.html. (accessed 21.10.2019). (In Russian)

Sultanova, R. R. (2000). Iskusstvo novykh gorodov Tatarstana [The Art of New Cities in Tatarstan]. 194 p. Kazan. (In Russian)
Sultanova, R. R. (2015). Tash mony. Melodiia kamnia [The Stone Melody]. 40 p. Catalog of the international symposium on sculpture. June 29-July 18, 2014. Kazan. (In Tatar, Russian, English)

Sultanova, R. R. (2019). Al'fiz Sabirov v zerkale traditsii [Alfiz Sabirov in the Mirror of Tradition]. Interview with M. M. Khabutdinova 6.09.2019. M. M. Khabutdinova's archive. (In Russian)

Tatarsko-russkiy slovar' $v \quad 2 \quad t$. (2007) [TatarRussian Dictionary in 2 Vols.] 726 p. Volume 1. Kazan, Megarif. (In Russian)

Valeev, F. Kh. (1975). Drevnee i srednevekovoe iskusstvo Srednego Povolzh'ia [Ancient and Medieval Art of the Middle Volga]. 216 p. Yoshkar-Ola, Map. kn. izd-vo. (In Russian)

Valeev, F. Kh., Valeeva-Suleimanova, G. F. (1975). Drevnee iskusstvo Tatarii [The Ancient Art of Tatariya]. 214 p. Kazan, Tat. kn. izd-vo. (In Russian)

Valeeva, D. K. (2003). Iskusstvo volzhskikh bulgar perioda Zolotoi Ordy [The Art of the Volga Bulgars of the Golden Horde]. 240 p. Kazan, Fiker. (In Russian)

Valeeva, D. K. (1999). Iskusstvo Tatarstana (XX vek) [The Art of Tatarstan ( $20^{\text {th }}$ century)]. 321 p. Kazan, Turan. (In Russian)

Vlasova, O. M. Avtorskiyi mif Al'fiza Sabirova [The Authorial Myth of Alfiz Sabirov]. URL: https://sabirovalfiz.nethouse.ru/articles/26128. (accessed 21.10.2019). (In Russian)

\title{
СКУЛЬПТОР ӘЛФИЗ САБИРОВ ИЖАТЫНДА БОРЫНГЫЛЫК НӘМ ХӘЗЕРГЕ ЗАМАН
}

\author{
Миләүшә Мөхәммәтжан кызы Хәбетдинова, \\ Казан федераль университеты, \\ Россия, 420008, Казан ш., Кремль ур., 18 нче йорт, \\ mileuscha@mail.ru.

\section{Луиза Фирдүс кызы Жамалиева,} \\ Казан федераль университеты, \\ Россия, 420008, Казан ш., Кремль ур., 18 нче йорт, \\ zamalluiza@mail.ru.
}

\begin{abstract}
Мәкалә татар скульпторы Әлфиз Сабиров ижатында авторлык мифологик образларын тикшерүгә, борынгы төрки тарих сюжетларын интерпретацияләү үзенчәлекләрен ачыклауга багышланган. Хезмәттә сәнгать белгечләренең Рәсәйдә һәм чит илләрдә күп кенә күргәзмәләрдә катнашкан яшь скульпторның ижаты турында фикерләре системага салынган, Мәкаләдә Ә.Сабировның әһәмиятле «артефактлары»ның тасвирламалары бирелгән. Сынчының 2019 елда Казанда булган «Аю бала» шәхси күргәзмәсендә тәкъдим ителгән эшләре тикшеренү материаллары булып тора.
\end{abstract}

Төп төшенчәләр: татар мәдәнияте, скульптура, Әлфиз Сабиров, мифология, образ, традиция.

Кереш

Сынчы Әлфиз Сабировның Казан Кремлендәге Татарстан Республикасы дәүләт сынлы сәнгать музееның «Хәзинә» милли сәнгать галереясында булган «Аю бала» күргәзмәсе (05.09.19 - 02.10.19) Казанның мәдәни тормы- 
шында игътибарга лаек вакыйга булды. «Атабабалардан - киләчәк буыннарга» шигаре сынчы хезмәтләрен караучыларга Ә. Сабировның шәхси мифологик дөньясын аңларга мөмкинлек биргән күргәзмәнең сәнгать концепциясен бик төгәл күрсәтә.

Пермь скульпторы Илья Глазунов исемендәге Россия рәсем сәнгате һәм архитектура академиясен тәмамлаган, Бөтенрәсәй күләмендәге ижади ижтимагый оешма - «Рәсәй рәссамнар берлеге» әгъзасы. «Аю бала» күргәзмәсе авторы 2017 елда Татарстан Республикасы Мәдәният министрлыгының Бакый Урманче исемендәге Дәүләт премиясенә лаек булган.

Хезмәтнең максаты - Пермь өлкәсендә туып үскән татар сынчысының Казанда 2019 елда тәкъдим ителгән күргәзмәсе нигезендә шәхси мифологиясе үзенчәлекләрен ачыклау.

\section{Материаллар һәм методлар}

Әлеге хезмәттә Ә. Сабиров ижатында төп пластик тенденцияләрне билгеләү һәм теоретик нигезләү максатында скульптура әсәрләренә формаль-стилистик анализ, төп эшләренең образ-пластик теле үзенчәлеген ачыкларга мөмкинлек биргән чагыштырмача-тарихи, төп темаларның образ-пластик чагылышында индивидуаль авторлык алымнарын тасвирлау методлары файдаланылды.

Ә. Сабировның «Аю бала» шәхси күргәзмәсендә тәкъдим ителгән скульптура хезмәтләре тикшерену объекты булып тора. Гыйльми эшнең фәнни яңалыгы беренче тапкыр скульптор Әлфиз Сабировның образлы-пластик теле үзенчәлекләрен анализлау омтылышыннан гыйбарәт.

Фәнни эшнең методологик нигезен татар халкының матди һәм рухи мәдәнияте тарихы ([Валеев], [Валеев, Валеева-Сулейманова], [Валеева, 1999], [Валеева, 2003], [Давлетшин], [Султанова, 2000], [Султанова, 2015], [Червонная] h.б.) hәм татар сынлы сәнгате [Кривошеева] буенча хезмәтләр тәшкил итә.

Фикер альишу

Әлфиз Сабиров 2004 елдан бирле Рәсәйдә («Легенда гласит / Легенда сөйли» (Пермь, 2011), «Арт-Казань» (Казань / Казан, 2011), «Большая Волга / Зур Идел» (Казань / Казан, Пермь, Москва / Мәскәу, 2011), «Арт-Пермь» (Пермь, 2011-2013), «Global art community» (Пермь, 2013) һәм чит илләрдә («От Урала до Атлантики / Уралдан Атлантикага» (Литва, Рига, 2014), «L'OURAL — artistes en mouvement» (Франция, Гренобль, 2014),
«Antichambre des merveilles» (Франция, Париж, 2015), «От Тихого океана до Атлантики / Тын океаннан Атлантикага» (Франция, Париж, 2015), «Русский дневник в Париже / Рус көндәлеге Парижда» (Франция, Париж, 2015), «Perm-Grenoble. Artisres croises» (Франция, Гренобль, 2016), «Nouvel artefact» (Франция, Париж, 2016), «Gardien» (Франция, Мексимье, 2016)) уздырылган күргәзмәләрдә актив катнаша.

Сынчының хезмәтләре Рәсәй (Москва / Мәскәү, С-Петербург, Екатеринбург, Пермь, Тюмень / Төмән, Красноярск) һәм шулай ук чит илләрдә (Париж, Гренобль, Нью-Йорк, Лондон, Рига, Токио) шәхси тупланмаларда саклана.

Казанда «Аю бала» күргәзмәсен ачу вакытында, кунаклар алдында чыгыш ясаганда, Ә. Сабиров скульптура белән Илья Глазунов исемендәге Россия рәсем сәнгате һәм арихитектура академиясенең Урал филиалында өченче курста укыганда шөгыльләнә башлавын әйтте.

Яшь сынчы зур күләмле сыннар ясап карарга һәм бронза белән эшләргә өйрәнергә тели. Шул вакыттан бирле бронза аның яраткан материалына, ә фактуралар белән уйнау, зур күләм һәм киселгән формалар аның үзенә генә хас ижат алымына әйләнә. Ә. Сабиров күп кенә эшләрендә металл һәм ташлар кушылмасын файдалана.

Иркутск милли тикшерену техник университетының дизайн һәм технологияләр кафедрасы мөдире, профессор Р. М. Лобацкая фикеренчә, Ә. Сабировның ижатын «интеллектуаль символизм» дип атарга мөмкин булган юнәлеш кысаларында карарга кирәк»: «Заманча станок скульптурасы - ул, гомумән, сынлы сәнгатьнең үзенчәлекле төре. Ул катлаулы, әмма бик киң һәм тәэсирле. Әлфиз Сабиров эшли торган юнәлешне интеллектуаль символизм дип атарга була. Аның өчен бер эштә төрле материалларны берләштерү, зәркән технологияләрен куллану, шулай ук этник тамырларга мөрәжәгать итү хас. Хәзер бөтен дөньяда этника гадәти булмаган эшләр белән үсә» (Цит.: [Кокин]).

Сәнгать белгече О.М. Власова күрсәткәнчә, «Әлфиз Сабиров ижаты нигезендә татар халкының традицияләре һәм эпосына бәйле шәхси мифология темасы өстенлек итә. Аның автор мифы геройлары hәм персонажлары үз чыганакларын билгеле бер этник төркемнең аерым эпизодларын тасвирлаучы легендаларда тапкан. Кырыс һәм хәрби дөнья персонажлары 
өчен реалистик трактовкасы булган күчмә халыкларны («Жиңелгән») яки көнчыгыш гүзәлләре образларын («Утыручы», «Айсылу») тарихи-иллюстратив категориягә кертү дә авыр. Бу ниндидер аллюзияләр, автор интерпретацияce həм «укырга» теләге, фикерләү һәм вакыт рухын тормышка ашыру дигән сүз.

Беренче карашка Әлфиз Сабиров сыннары артык абстракт һәм катлаулы идентификацияләнүче булып күренергә мөмкин, чөнки алар бик күп символлар һәм мәгънәләр белән сугарылган. Экзотик темалар, архаика һәм хәзерге заманның сәер кушылмасы, реминисценцияләр күплеге һәм формада халык эпосы белән постмодернистик алымнарның кушылып китүе оригиналь авторлык манерасы тудыра» [О.М. Власова белән интервью].

Ә. Сабиров интервьюларында, үзенең авторлык мифологиясен формалаштыру өчен, жирлек булып, төрки мифология хезмәт итте, дип билгеләп үтә. Скульптор О. Роден, Г. Мура, К. Бранкузи, Б. Урманче ижатыннан илһам ала.

Сәнгать белгече Р.Солтанова фикеренчә, «Ә. Сабиров ижаты Көнчыгыш төрки нигездә, илаһи рухта илһам алып үсә, тирән мәхәббәттән килә»: «Үз ижатына пластик идеяләр өчен ул, беренче чиратта, мифологик күзаллауларда һәм халык ышануларында лаеклы чыганак тапты. Ул Идел Буе Болгарының борынгы төрки гамәли сәнгате белән тыгыз бәйләнгән этник юнәлешле татар скульптурасын үстерү үзәгендә тора.

Сабиров Татарстан скульптурасын 1970 еллар башында ук рәссам-монументалист Илдар Ханов тарафыннан ачылган постмодернизм юнәлешендә алга таба үстерү юлларын киңәйтә.

Яшь скульптор, Ханов кебек үк, модернизм тенденцияләрен кулланып, милли архаиканың күләмле фикерләү архетипларын пластик форма аша тапшыра.

Сабиров милли гореф-гадәтләрнең үсешенә үзенчәлекле юл сала. Бу формаль телдә генә түгел, ә бәлки Көнчыгыш сәнгатенә һәм татарларның сәнгати фикеренә хас булган ассоциативлык, күпмәгънәлелек, әйтеп бетермәүдә чагылыш таба, аның әсәрләрендә борынгы этник стилистика həм рус-европа мәктәбе алымнары яраша ала.

Кайбер эшләрдәге мөселман традицияләре сурәтләр булмауда, сызыклар, каллиграфия бәйләнешендә, арабескаларга охшату кебек үзенчәлекләрдә чагыла.
Яшь скульптор Әлфиз Сабиров үзенең ижаты белән хәзерге сәнгатьтә бер традиция нигезендә генә эшләү катлаулы булуын тагын бер кат раслый: дөнья сәнгатенең авангард юнәлешләре төрле мәдәниятләр синтезына юл ачты» [Султанова, 2019].

Ә. Сабиров үз эшләрен һәм күргәзмәләрен исемләгәндә, аңлы рәвештә төрки сүзләрдән файдалана. Шул рәвешле скульптор аларны «ишекләр»нең яңа, башка дөньяга «ачкыч»ларына әверелдерә. Сынчы үз тарихын булдырырга омтыла, шуңа күрә туган тел потенциалына мөрәжәгать итә.

Туган тел байлыгы турында уйланып, Ә. Сабиров «В контакте» социаль челтәрендә 2019 елның 14 августында түбәндәге эчтәлекле пост язды: «Ат, яу, аю, ут, су, аш, уй, ул - болар барысы да ике хәрефтән торган татар сүзләре. Аларның кайберләре минем сыннарда очратырга мөмкин. Мин эшнең ничек аталуына, яңгырашына зур игътибар бирәм. Бу сүзләрдә фундамент та, көч тә, борынгылык та, вакыт та бар. Сүзләрне дәвам итәргә мөмкин: аз, ял, ят, ук, ит, ию, ас, ай, ел, яз, ил ...». Татар язучысы Марсель Галиев фикеренчә «иң кадерле, олы йөрәкле сүзләр, ут-ялкынын тирәнгә, бәгыренә кысып, нибары өч авазга сыйган:

«Жир. Күк. Кан. Тән. Моң. Дин. Жан. Рух» ${ }^{1}$.

Бер сулышка сыярлык иң кыска сүзләр («Рух» («Поэзия духа»)) [Галиев, с.39].

Скульптор шәхси күргәзмәләренә исемнәрне бик уйлап сайлый. Мәсәлән, Ә. Сабировның 2013 елда Пермьдә ачылган күргәзмәсе «Көмешташтан. Рожденный из жемчуга» дип атала. Татарча «көмешташтан» «көмеш таштан туган» дип тәржемә ителә. Авторлык интенциясенең асылын житкерергә омтылып, скульптор русча «Энже бөртегеннән туган» дигән исемне кабатлый. Шул рәвешле, скульптор үз эшләре семантикасының күп катламлы характерын күрсәтә.

«Көмешташтан. Из жемчуга» скульптурасыннан эчке көч бөркелеп тора (Бронза, литье. 2013. 9х21х19). Мифологик жан иясенең панциреннән аның героик асылы күренеп торган кебек хис туа. Бронза мөгезләр алтын белән шомартылган.

Ә. Сабиров, образларны турыдан-туры аңлаудан котылу өчен, таныш сүзгә үзгәрешләр кертә, чөнки нарратив катлам образның бер өлешенә әверелә. 2014 елда Пермьдә

\footnotetext{
${ }^{1}$ Земля. Небо. Кровь. Тело. Песнь. Вера. Душа. Дух. (тат.).
} 
оештырылган күргәзмәсен ул «Батор. Кагылу» дип атый. Скульпторның һәр күргәзмәсендә лейтмотив буларак герой булса да, ул төрки телләрдә гадәттә әкият һәм легенда геройларын атаган «батыр» сүзеннән («баһадир, батыр сугышчы») баш тарта [Татарско-русский словарь, с. 207]. Образ тарафыннан аерым вакыт аралыгында кичерелә торган трансформация процессын тирәнрәк белдерергә омтылып, скульптор бу процессны тышкы яктан гына түгел, эчке яктан да күрсәтә. Әйтик «Батор/Прикосновение» скульптурасында (Бронза, литье. 2014. 43×27x17) (Bator / Touch. Bronze, moulding. 2014. 43×27x17) Ә. Сабиров герое, яшәешнең яңа шартларында, бозваткыч кебек, вакыт чикләрен жимерә һәм үзгәрешләр кичерә.

Скульптор әлеге нарратив алымга «Балла» исемен сайлаганда да мөрәжәгать итә (Бронза, литье. 2013. 11×8x6) (Balla. Bronze, moulding. 2013. 11х8x6). (чагыштыр: «бала» («бала, сабый)). Автор махсус рәвештә ике л хәрефе яза, шул рәвешле сүз жырлап тора һәм аеруча серле булып тоела. Безнең алда кечкенә кыз. Үрелгән чәч толымнары аны саклау вазифасын үти, ә төз сылу гәүдәсе аны патша кызы дип фаразларга мөмкинлек бирә.

«Ат / Конь» скульптурасында (Бронза, литье. 2013. 11x14x5) («At/Horse». Bronze, moulding. 2013. 11х14x5) Ә. Сабиров геройларның төрки мифлардан килгән яклаучысының көчен hәм яхшы энергетикасын бронзада гамәлгә ашырырга омтыла. Төсләр фактурасы белән уйнау мәгънә өсти һәм игътибарны жәлеп итә: гасырлар аша безнең каршыга батырның тылсымлы тугры дусты һәм ярдәмчесе алмачуар ат килеп чыга кебек. Ат дала тормышының аерылгысыз өлеше булып тора, ул кешегә яшәргә һәм исән калырга ярдәм итә, шуңа күрә скульптор үз эшендә атның жир белән тыгыз бәйләнешен һәм хайванның кешегә терәк булуын тапшырырга омтыла.

Сәнгать белгече Виктория Котдусова «Ә. Сабиров ике төрле мәгънә белән уйный. Ул аның кайда уңышлы килеп чыгуын белә», - дип саный. Скульптор «формалар белән оста эшли, тән һәм ишарәләр теле аша ачыла торган эмоциональ эчке халәтне оста тапшыра. Автор Y3 ижаты белән форма hәм эчтәлекнең мавыктыргыч уенын күрсәтә, бронза ярдәмендә ул тирән эчке көчкә ия һәм көтелмәгән эффект тудыручы искиткеч скульптуралар ясый».

«Әлфизнең эшләрен караганда, аларда ниндидер сер барлыгын тоясың. Ул ясаган сыннар әле һаман трансформация процессында һәм Үзгәрештә кебек. Әйтерсең лә алар космостан төшкән һәм безнең жир патшалыгында катып калганнар кебек.

Сызыклар hәм формалар ирекле ритм тудыра, эшнең чикләре төгәл түгел, һәм бу ритм сезне алга алып китә, сезнең караш, салмак кына, һәрберсенең үз көе, әйдәп баручы мотивы булган сыннарның берсеннән икенчесенә күчә. Әлфизнең скульптуралары күзаллауны уятып жибәрә, һәм аларга яшеренгән серләрне эзләргә мәжбүр итә», дип, үзенең фикерләре белән уртаклаша сәнгать белгече Виктория Кутдусова [Кутдусова. Аннотация выставки].

Әйтик, Барс Табар образында (Барс Табар 2. Бронза. Литье. 2013. 34х33×14) Ә. Сабиров мифик затны заманнар үрелешендә чагылдырырга омтыла. Тупас, кытыршы таш тән борынгылыкны чагылдырса, бик яхшы шомартылган биттә без бүгенгенең чагылышын күрәбез. Берсеннән икенчесенә талгын гына күчкән форма, безнең карашка, вакытлар чигенә хас динамик характерны гәүдәләндерә.

Вакыт идеясе корпусның тупас рельефының Үзгәреп торган әйләнә-тирәлек белән кушылмасында чагылыш тапса, хәрәкәтләр мифик затның атамасында ачык күренә («табар» сүзе «эзләгән табар» дигән мәгънәне белдерә). Аның кытыршы тәне без профильдә күрә торган бер күзле шомартылган битне тагын да ачык күрсәтә.

Ә. Сабиров үзе турында миф тудыра. Моны аның «Кылычлы малай» дип исемләнгән беренче сыны раслый (Бронза, литье. 2009. 6х6х2) раслый. Скульпторның яшь герое киләчәккә омтыла, ул тормыш белән очрашуга әзер. Уенчык кылыч аның гәүдәсенә ышаныч hәм көч өсти. Малайның чәче төрки халыклар традициясенә дан жырлый. Күчмә халыкларда кекил - чәчне алган вакытта калдырылган бер тотым чәч. Ул күз тиюдән саклый дип ышанганнар. Бөек дала төрки халыкларында ир-егетләр чәченең aйдар - дип аталган формасы да булуы билгеле. Чәчне алдырганда, баш түбәсендә яки артында бер тотым чәч киселмәгән. Уңайлы булсын өчен аны үреп йөрткәннәр. Ир-атларның мондый прическасы тәңречелек тарафдарлары тарафыннан күз тиюдән саклану формасы булган.

Алга таба бу образ нигезендә Ә. Сабиров «Кечкенә сугышчы. Шлем» образын ижат итә (Бронза, литье. 20x17x7.). Бу сында авыр шлем hәм баланың жансыз фигурасын капма-каршы 
кую аркасында конфликт барлыкка килә. Скульптор малайның авыр йөккә каршы тору энергиясен динамикада тапшыруга ирешкән. Малайның ялан аяклары егылмас өчен эчкә карап тора, шлемындагы aйдары югарыга омтыла. Бу исә тамашачыда киләчәктә аның чын сугышчыга, саклаучыга әверелүенә өмет уята. Шлем һәм кылычның материаллар фактурасы да сынны кабул итүгә зур йогынты ясый.

Шлем тигез түгел, ул берничә катлы, әйтерсең лә, сугышларда үлеп калган геройларны искә төшерә кебек. Ә саклану идеясе шлемда гына түгел, саклаучы-чәч толымы деталендә дә чагылыш таба. Скульптурада хәрби шлемга өйрәнүләр вакытында кулланылган агач кылыч каршы куела. Бу образларның антитезасы тамашачыга вакыт хәрәкәтен, буыннар алмашын күрергә ярдәм итә.

Бу фикер шлемдагы буш күз уемы аша да үстерелә. Аның аша карап без тигез рәтләр булып тезелгән борынгы яугирләрне күрәбез. Баланың шома тәне һәм шлемның рельефлы өслеге буыннар бәйләнеше, күчеш һәм геройлык хакында сөйли. Малайның кул куелышы һәм калкан аның киләчәктә батырлык эшләячәген күрсәтә.

Геройның эчке көченә дан жырлаучы «Жиңелгән. 2» (Бронза, литье. 2013. 24х18х15) скульптурасы да бездә зур кызыксыну уятты. Сәнгать белгече О.В. Власова Ә. Сабиров әсәрләренең тематикасы «татар халкының яшәү hәм үлем, көрәш һәм тынычлык, фажигале үлем hәм яшәешнең югары поэзиясе хакында бәян итүче эпик төр әсәрләре - мифлар һәм легендаларга нигезләнгән. Автор күзаллавында табигать һәм кеше тормышның виталь энергияне көчле омтылыш белән жибәрүче бердәй законнары белән бәйләнгән» - дип билгели [Власова]. «Жиңелгән.2» скульптурасында көтмәгәндә аркасына дошман угы кадалган сугышчы образы мәңгеләштерелгән. Катлаулы ситуациядә калгач та, ул Y3 принципларына тугрылыгын саклый каршылык күрсәтә. Каяндыр очып килгән укка караганда, сугышчының иелгән башы, як-якка салынып төшкән куллары, кысылган иреннәре, чәч толымының бер якка авышлыгы мөһимрәк. Сугышчының кыяфәте бик нык, аның битендә тиздән үлем белән очрашуны аңлаудан борчылу, кайгыру төсмерләре юк. Авторның ижади фикерләвенә хас булганча, скульптураның өслеге юри тупас һәм аскетик ясалган, «вакыт юшкыны» - патина белән капланган. Скульптураның исеме сугышчы фигурасы белән ниндидер конфронтациягә керә, тамашачыларга кешегә яшеренгән рухи көчне hәм тормышның бөеклеген күрсәтә. Автор белдергәнчә, ул тормыш һәм үлем янәшә булган яшәеш парадоксын күрсәтергә теләгән.

Скульпторның борынгы төрки мифология образлары белән туган авылында булган вакыйгалар һәм легендалар турындагы балачак истәлекләрен органик рәвештә берләштерә алуы гажәпләндерә. «Төшләрендә күргән, балачак истәлекләреннән килгән, хыялларында туган образларга нигезләнеп, ул структур яктан гажәеп катлаулы, әмма бик таныш образлар тудыра. Аның эшләрендә безгә таныш күп элементларны күрәбез.

«həр сында, аның өслегенә беркетелгән ниндидер шәхси мәгълүматлар бар. Каршыбыздагы аның туган авылындагы бермөгезлеләр, серле патша кызлары, мифик затлар, серле жәнлекләр катнашындагы уенны күзәткән вакытта, узган меңьеллыкларның барлык мәдәни мирасы күз алдында пәйда булган кебек тоела», - дип саный В. Кутдусова. - «hәр фигура үзенчәлекле, уникаль һәм матур. Төп геройлар арасында «Безнең авыл бермөгезе» - (Бронза, литье. 2010. 9х20х12) бер мөгезле, көчле, базык гәүдәле ниндидер бөкре, зәгыйфь, әмма шул ук вакытта тормыш көчен югалтмаган үгез. Шулай ук алты аяклы «Ат. Конь» (Бронза, литье. 2013. 13×15×5.), hәм «Каравылчы / Страж» (Бронза, литье. 2011. 26x15x5.), hәм «Аждаха» (дракон) (Бронза, литье. 2011. 14x20x9) hәм «Тай Кыз» (Бронза, литье. 2011. 13х11х4) hәм алты аяклы ат белән кушылып киткән жайдак сыны «Яңа кентавр» (Бронза, литье. 2017. 34х12x18)» [Кутдусова].

Ә. Сабиров үз эшләрен турыдан-туры эпос белән бәйле дип санамый. Ул, Үз шәхси фантазиясенә нигезләнеп, хәтта фантасмагорик образлар тудыра. Әлфизнең скульптураларындагы этник сызыклар - нәсел тамырларының чагылышы.

Рәссам яңа, бик шәхси мифология тудыра, анда борынгы этник мифлар, әйтерсең, мультимедиа программасы аша үткәннәр. Бу архаиканың hәм заманның гажәеп органик кушылмасын рәссам фактуралар уены белән ассызыклый: аның скульптураларында еш кына бер үк вакытта эшкәртелмәгән кытыршы, тузанлы өслек шомартылган, бронза алтыны белән ялтырап торучы өслек белән янәшә куела. 
Сәнгать белгече О.М.Власова фикеренчә, Ә. Сабировка «аңсыз эмоциональлек: атлар, хатын-кыз матурлыгы, ир-ат батырлыгы» хас. Әлфизнең эшләрен караганда, аларда ниндидер cep hәм тылсым яшеренгәнен аңлыйсың. Скульптуралар һаман да трансформация һәм үзгәреш процессында кебек тоела. Алар гүя башка дөньядан, әйтерсең, космостан егылып төшкән һәм безнең Жир патшалыгында суынган» ([О. М. Власова белән интервью]).

Хатын-кыз темасына ижат ителгән скульптуралар арасында «Принцесса. 2» аерылып тора (Бронза, камень, литье. 2017. 29x12x9). (Princess 2. Bronze, stone, moulding. 2017. 29x12x9). Назлы, нәзәкатьле, ә бәлки көйсез яшьүсмер кызның кулында ниндидер бөртек: бөтен тереклекнең символы булган орлык бөртегеме, әллә күк символы булган энже бөртегеме? Бу скульптура тынычлыкны, киләчәккә ышанычны белдерә.

«Су кыз» образында да гармония һәм эчке халәт рухы сизелә (Бронза, литье, дерево. 2013. $39 x 28 x 12)$. Тәне яшел патина белән капланган серле су кызы хатын-кыз анатомиясе хакындагы күзалауларны жимерә. Скульптор Yз-үзенә нык ышанган образ тудырган. Су өстендә нинди генә штормнар булмасын, алар кызның эчке халәтен, рухи тынычлыгын боза алмый.

Ана темасы скульптор тарафыннан «Ана арслан» фигурасында да бик үзенчәлекле тормышка ашырылган (Бронза, литье. 2014. $16 \times 33 \times 9)$.

«Кыз», «Патша кызы», «Диңгез турында истәлекләр», «Баш сөяге», «Беренче көн таңы» - пластик яктан бик төрле образлар. О. М. Власова күрсәткәнчә, «скульптураларның композицияләре катлауы һәм вариатив. Кайберләрендә кискен хәрәкәт, икенчеләрендә - «архаик» хәрәкәтсезлек һәм тынлык чагылдырылган, барлык формалар кубка кертелгән һәм аерым ярусларга бүленгән кебек.

Нәкъ менә шундый композицияләрдә Көнчыгыш скульптурасы традицияләре сизелә. Фактураны эшкәртү зур нәтижә бирә. Кайдадыр кытыршы табигый өслек калган, кайдадыр бронза күз явын алырлык алтын балкышка кадәр эшкәртелгән. Таш итәк ныклыкны, сыгылмалылыкны; материалның, чокып ясалу, кайвакытта инкрустация, яки агач hәм кабырчыклар кертелү сәбәпле, жанлы булып күренгән матурлыгын ассызыклый.

Рәссамны пластика һәм киңлекнең үзара бәйләнешен булдырган фактуралар, материал- лар уены кулланылган скульптура жәлеп итүе сизелеп тора.

Хәзерге сәнгатьтә һәр әсәр тамашачыдан тирән белем һәм күзаллау таләп иткән символга әверелә. Мәңгелек тормыш кыйммәтләренең драматик тарихын həм шигъриятен тоеп эшләүче рәссамның һәр эшендә бу омтылышларны күрергә мөмкин» [Власова].

«Бүген жәмгыять тормышы бик кызу темпта бара, шуна күрә аерым детальләргә игътибар итәргә вакыт калмый. Сәнгать белгече В.Кутдусова фикеренчә, Ә. Сабиров хезмәтләре безне чорнап алган хаосны туктата һәм тынлыкта туктап калырга чакыра» [Кутдусова].

Игътибарыбызны рәссамның «Тамчи/Тамчы»әсәре жәлеп итте (Бронза, литье/кою, серебрение/көмешләү, фианиты/ фианитлар 2013. 3x9x4 мм). Дымның яшәү көче рубин төсендәге фианиттан ясалган күзләре ерак максатларга төбәлгән мифик коңгызның авызына капкан зәңгәрсу фиантитта чагылыш тапкан. Безнең карашка, бу скульптура мәңгелек хакыйкать эзләүне, мәңгелек хәрәкәтне гәүдәләндерә.

Рәссамның пульсацияләүче фикере диңгез скаты формасында булган «Йокысызлык» образында гәүдәләнеш тапкан (Бронза, литье. 2013. 41x61x11) (Insomnia 2. Bronze, moulding. 2013. 41х61x11.). Автор фикерләрнең уяулык ситуациясендәге актив халәтен психологик яктан дөрес итеп бирүгә ирешкән. Моны тапшыру өчен, скульптор дулкын өслегенә бик күп күзләр ясаган. Йокысызлык, су кебек киңлек буенча тарала һәм Yз корбанын сиздермичә генә каплап ала. Шомартылган өслек тиз үзгәрешне һәм әйләнә-тирәлектәге төсләрне үзенә алу мөмкинлеген чагылдыра.

Ә. Сабиров татар, борынгы грек, Кытай h. б. милләтләр мәдәниятләренә караган визуаль элементлардан торган синкретик образ булдырырга омтылуын әйтә. Нәкъ менә «төрле мәдәниятләр микс»ы - скульптор өчен шәхси тарихын сөйләү алымы.

Үз тамашачысы белән диалог төзү өчен, скульптор образның эчке тулылыгын күрсәтергә омтыла. Караучыларның күзаллауларын стимуллаштыру максатыннан, Ә. Сабиров киселгән элементлар белән эшли. Бу безгә кадәр кыйпылчыклар рәвешендә килеп житкән həм археология музейларында саклана торган яңа артефактлар [Беломестнова].

Ә. Сабиров үзен классик булмаган скульптура тарафдары дип атый: «Мин формаларны hәм күләмнәрне жимерергә (бу 
жимерелү аша - мифологик контекстта образны яңадан торгызуга), шулай ук төрле, әйтик, тупас һәм бик яхшы шомартылган фактураларны үзара яраштырырга омтылам. Күзгә ташланган көтелмәгәнлек, пропорциональ үзгәрешләр тамашачыны жәлеп итә һәм образларга яңа караш тудыра. Хәер, кайбер кешеләрдә алар кискен ризасызлык уята» [Беломестнова].

Скульптор әйләнә-тирә дөньяның ике төрлелеген күрсәтергә омтыла. Ир-атлар һәм хатын-кызлар, ныклык һәм агымлылык, линия həм фактуралар, төсләр һәм формалар арасындагы бердәмлек һәм көрәш. Аның эшләрендә рәссамга илһам биргән тарихи үткәннәр, борынгы Грециядән, Римнан һәм Вавилоннан килгән мифик персонажлар барлыгы сизелә.

Ә. Сабиров танылган образларга яңа мәгънә өстәүдән курыкмый. Мәсәлән, Роденнын «Фикер иясе» безнең заманда бөтенләй башкача күренә. Ул хәзерге дөнья кебек үк күпкә катлаулырак яңадан туу юлында сыман.

\section{Нәтижсзләр}

Скульпторның Казандагы күргәзмәсенә куелган төп сын - «Аю бала» (Бронза, литье. 2017. 39x32x24). Татарча бала-аю мәгънәсендә. Әлеге образ Ә. Сабировның балачак истәлекләре белән бәйле. Скульптор үскән гаиләдә балага «Аю бала кебек таза бул!», «Аю кебек кыю бул!», «Исеңдә тот, син Акбүре ыруыннан!» дигән теләкләр әйтелгән.

Үзенең хезмәтләрендә беренчеләрдән булып «Айыу туйы» бәйрәме турында язучы фольклорчы М.X. Минһажетдинов, әкият геройларының могжизалы рәвештә аюдан туу мотивы төрки-монгол этнокультурасыннан башланып, алардан башка халыклар фольклорына күчкән дигән фаразны әйтә. [Могильников, с. 156-157]. Омск өлкәсенең Усть-Ишем районы Эбаркуль авылында (курдак-саргат татарлары) урман хужасын Аю Бабай -дип атаганнар. Аю Бабай образы белән аю хакындагы күзаллаулар һәм аю культы бик тыгыз бәйләнгән [Ярзуткина].

И. В. Белич, үзенең эзләнүләрендә, бараба татарларының һөнәрчелек культын анализлап, бараба аучыларының ау вакытында кулланган тыюлары, «уңыш китерә» дип ышанган амулетларын тасвирлый [Белич].

Скульптор әлеге эшендә ата-ананың бала тәрбиясендәге ролен ассызыкларга теләвен әйтә: «Сабый чактан ук бала, әти-әнисе тарафыннан буыннан-буынга программалашты- рыла торган саклау, яклау астына алына». Скульптурада конфликтка авыр битлек һәм якланмаганлыкның символы булган ялан үкчәсе (чаг. «Ахиллес үкчәсе») күренеп торган сабый бала гәүдәсе арасындагы контраст аша ирешелә. Баланың нинди белем һәм традицияләр белән киләчәккә атлавы тулаем ата-анасына бәйле. Яңа туган балага яшәү көче бирүчеләр - нәкъ менә алар.

Ә. Сабиров борынгы төрки мәдәният традицияләрен үзләштерү юлына аяк басты, киләчәктә «Аю бала»дан бөек Бакый Урманче традицияләрен лаеклы дәвам итүче «Аю Бабай» үсеп чыгар, дип ышанасы килә.

«Сынчы Әлфиз Сабировның күргәзмәдә тәкъдим ителгән эшләре һәрберебез күңелендә яшәгән геройның татар халкының горефгадәтләренә нигезләнгән сихри мифология дөньясына сәяхәте кебек. Күргәзмәнең шигаре - «Ата-бабалардан - киләчәк буыннарга».

Бу сәяхәт барышында тамашачы хтоник гигантлар, мифик хайваннар, геройлар һәм Аллалар образларын күзәтә алачак, алар кешеләргә яшәешнең мәхәббәт һәм нәфрәт, хаос һәм космос, яшәү һәм үлем, борынгылык hәм яңалык арасындагы мөнәсәбәтләр парадоксларын аңларга ярдәм итә ала.

Конфликтлар һәм әверелешләр буыннарны бәйләп торучы вакытлар чигендә чагылыш табалар. Скульптуралар үзләре исә, әйтерсең лә, кешеләр күз алдында трансформацияләнеп торучы күчмә формаларда [«Аю бала» күргәзмәсе аннотациясе].

\section{Әдәбият}

Аннотация выставки «Аю бала» (Казань, 2019).

Белич И. В. Природа в доисламских верованиях сибирских татар (конец XIX начало XX вв.) // Культурные и хозяйственные традиции народов Западной Сибири. Новосибирск, 1989. С. 133-140.

Белич И. В. Культ медведя у сибирских татар // Обские Угры. Материалы II Сибирского симпозиума «Культурное наследие народов Западной Сибири» (12 16 декабря, 1999 г., г. Тобольск). Тобольск; Омск, 1999. С. 86-90.

Беломестнова А. Новые артефакты Альфиза Сабирова // Berlogos. 15.12.2016. URL: http://www.berlogos.ru/interview/novye-artefaktyalfiza-sabirova/

Валеев Ф. Х. Древнее и средневековое искусство Среднего Поволжья. Йошкар-Ола: Мар. кн. изд-во, 1975. $216 \mathrm{c}$.

Валеев Ф. Х., Валеева-Сулейманова Г. Ф. Древнее искусство Татарии. Казань: Тат. кн. изд-во, 1985. $204 \mathrm{c}$. 
Валеева Д. К. Искусство волжских булгар периода Золотой Орды (XШ-XV вв.) Казань: Фикер, 2003. 240 c.

Валеева Д. К. Искусство Татарстана (XX век). Казань: изд-во «Туран», 1999. 321 с.

Власова О. М. Авторский миф Альфиза Сабирова. URL: https://sabirov-alfiz.nethouse.ru/ articles/26128 (дата обращения 21.10.2019).

Галиев М. Рух. Поэзия духа. Казань: Тат. кн. изд-во, 2014. $271 \mathrm{c.}$

Давлетшин Г. М. Очерки по истории духовной культуры предков татарского народа (истоки, становление, развитие). Казань: Тат. кн. изд-во, 2004. 431c.

Интервью с Власовой О. М. // Личный архив Альфиза Сабирова.

Кокин $A$. Интеллектуальный символизм А. Сабирова // Аргументы недели. Иркутск. 2017. № 3 (545). 17 января.

Кривошеева Т. Н. Скульптура Татарстана: истоки, становление, традиции. Казань: Отечество, 2013. $256 \mathrm{c}$.

Кутдусова В. Мифологическое сознание. Эстетика мифа. Аннотация выставки.

Кутдусова B. Сабиров $A$. Пермь. URL: http://www.yarmarka.ru/content/2016/art_russia/catalog /sabirov.html (дата обращения 21.10.2019).

Могильников В. А. К вопросу о связях населения Башкирии и Зауралья в конце I тысячелетия до н.э. -
1 тысячелетии н. э. // Археология и этнография Башкирии. Уфа, 1971. Т. 4. С. 151-157.

Панджариди В. Мифы и легенды Альфиза Сабирова // Информационное агентство «Магнезия». 10.09.2016. URL: https://www.mngz.ru/russia-worldsensation/2222342-mify-i-legendy-alfiza-sabirova.html (дата обращения 21.10.2019).

Султанова Р. Р. Искусство новых городов Татарстана. Казань, 2000194 с

Султанова Р. Р. Таш моңы. Мелодия камня. The stone Melody. Каталог международного симпозиума по скульптуре. 29 июня - 18 июля 2014 г. (тат, рус., англ. яз.) Казань, 2015. 40 с.: ил.

Султанова Р. Р. Альфиз Сабиров в зеркале традиции / интервью с М. М. Хабутдиновой // Архив М. М. Хабутдиновой. 6.09.2019.

Татарско-русский словарь в 2 т. Т. 1. Казан: Мәгариф, 2007. 726 б.

Червонная С. М. Искусство Татарии. История изобразительного искусства и архитектуры с древнейших времен до 1917 года. М.: Искусство, 1987. $352 \mathrm{c}$.

Ярзуткина А. А. Традиционные земледельческие, скотоводческие и промысловые культуры сибирский татар: автореферат дис. на соискание уч. ст. канд. ист.н. Омск: изд-во Омского гос. ун-та, 2004. $18 \mathrm{c}$.

\title{
СПЛАВ АРХАИКИ И СОВРЕМЕННОСТИ В ТВОРЧЕСТВЕ СКУЛЬПТОРА АЛЬФИЗА САБИРОВА
}

\author{
Милеуша Мухаметзяновна Хабутдинова, \\ Казанский федеральный университет, \\ Россия, 420008, г. Казань, ул. Кремлевская, д. 18, \\ mileuscha@mail.ru. \\ Луиза Фирдусовна Замалиева, \\ Казанский федеральный университет, \\ Россия, 420008, г. Казань, ул. Кремлевская, д. 18, \\ zamalluiza@mail.ru.
}

\begin{abstract}
Статья посвящена исследованию авторских мифологических образов в творчестве татарского скульптора Альфиза Сабирова, выявлению специфики интерпретации сюжетов древнетюркской истории. В работе систематизированы отзывы искусствоведов о творчестве молодого скульптора, участника целого ряда выставок как в России, так и за рубежом. В статье даны описания знаковых «артефактов» А. Сабирова. Материалом исследования выступают работы, представленные на Персональной выставке в Казани «Аю бала» (2019).
\end{abstract}

Ключевые слова: татарская культура, скульптура, Альфиз Сабиров, мифология, образ, традиция. 